\title{
Pärimusliku ajaloo uurimine Eesti ja naabermaade koostööruumis ${ }^{1}$
}

\author{
Tiiu Jaago, Ene Kõresaar
}

\begin{abstract}
Teesid: Artiklis antakse ülevaade viimase 12 aasta jooksul kujundatud Eesti pärimusliku ajaloo ja eluloouurijate koostööst Läti, Leedu ja Soome uurijatega. Koostöö on valdkondadevaheline: Soome koostööpartnerid on folkloristid, Läti ja Leedu koostööpartnerid sotsioloogid, Eestis on koostöösse hõlmatud uurijate ring interdistsiplinaarsem. Pärimusliku ajaloo mõistet avatakse lähimõistete 'suuline ajalugu' ja 'eluloouurimine' ('biograafiline meetod') kaudu. Keskendutakse koostöös ilmnenud ühisosale ja erinevustele meetodite, terminoloogia ja uurimisküsimuste alal. Näidatakse, kuidas teadus (terminoloogiast uurimisküsimusteni) on ühelt poolt seotud teaduse arengu ajaloolise mõõtmega ja teiselt poolt dialoogiga ühises mõtteruumis. Lähemalt vaadeldakse kõnesoleva koostööruumi dialoogi puutepunkte, mis koonduvad kategooriatesse 'suuline', 'kirjalik' ja 'sündmus' ning kujutavad endast kompleksi kogemusest, tõsielust ja väljendusest.
\end{abstract}

Märksõnad: Balti-Soome koostöö, eluloouurimine, pärimuslik ajalugu, suuline ajalugu, suuline ja kirjalik kultuur, sündmus

\section{Pärimusliku ajaloo uurimine kui koostööruum}

Eesti eluloo- ja pärimusliku ajaloo uurijad on olnud 1997. aastast alates kontaktis Soome pärimusliku ajaloo (muistitietotutkimus) uurijatega. ${ }^{2}$ Koostöö üheks esimeseks väljundiks oli soome perepärimuse uurija Pauliina Latvala artikli "Soomlase elu kujutamine pärimuslikus ajaloos” avaldamine Mäetaguste 11. numbris (Latvala 1999), millele samas avaldati ka Eesti-kesksed kommentaarid (Jaago 1999; Kõresaar 1999). 2000. aastal laienes uurijate koostöö Lätti, millele pani aluse 11. ja 12. mail Tartu Ülikooli eesti ja võrdleva rahvaluule õppetooli eestvedamisel toimunud pärimusliku ajaloo seminar. Sellest kasvas välja artiklite kogumik Pärimuslik ajalugu (Jaago 2001). Järgnevatel aastatel on koostöö Soome folkloristidest pärimusliku ajaloo ning Läti sotsioloogidest elulugude ja suulise ajaloo uurijate vahel tihenenud ja mitmekesis- 


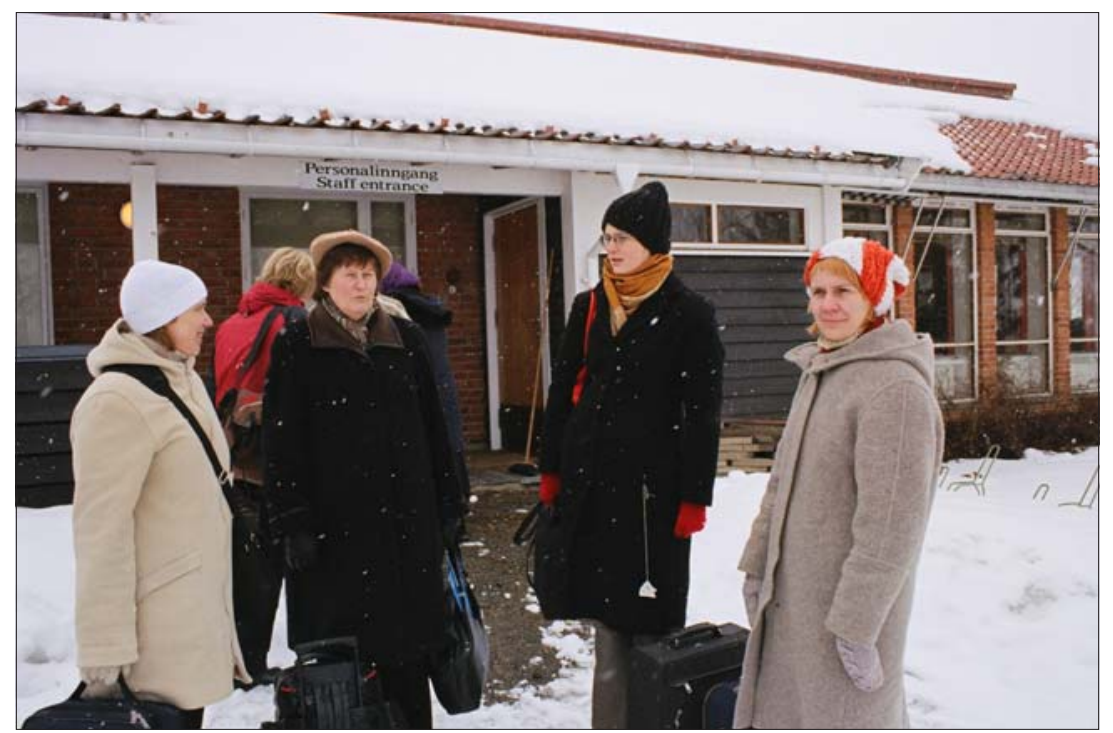

Eesti uurijad pärimusliku ajaloo uurimise koostööseminaril "Migration and Oral History” Hamaris, Norras 2006. aastal. Vasakult: Tiiu Jaago, Rutt Hinrikus, Kirsti Jõesalu, Riina Reinvelt. Ieva Garda foto 2006.

tunud. Palju sellest toimus ühenduse Eesti Elulood tegevuse raames. Suhtlusvõrgustikule lisaks saab kõnelda ühisseminaridest ja konverentsidest, aga ka väljaannetest, kus on rohkem või vähem kajastunud ka selle koostöö tulemused. ${ }^{3}$

Mäetaguste käesolev pärimuslikku ajalugu käsitlev teemanumber kujunes vajadusest piiritleda praegune uurimisetapp kõnesolevas koostöövõrgustikus. See keskendub Läti, Leedu ja Soome uurijate tegevusele, tutvustades ühelt poolt ühiste suundadega töörühma tegevust üldisemalt, pidades aga teiselt poolt silmas eestikeelse teadusruumi praegusi huvipunkte. Kirsti Salmi-Niklanderi (2001) ja Baiba Bela (Bela-Krūmiņa 2001) töid on eesti keeles avaldatud ka varem, ent Jyrki Pöysä (Joensuu ülikool), Maruta Pranka (Läti Ülikool, Riia), Irēna Saleniece (Daugavpilsi ülikool) artiklid ilmuvad eesti keeles esmakordselt. Lisandunud on ka uus piirkond - Leedu, kust kaastöö selle teemanumbri jaoks kirjutas Irēna Šutinienè (Vilniuse Sotsiaaluuringute Instituut). Teemaartiklitele lisandub Tamara Gauzova, Larisa Ženina, Ludmilla Andrejeva, Gulsina Seljaninova ülevaade suulise ajaloo alasest kogumis- ja uurimistööst Permi ülikooli juures, mis avab eestikeelsele lugejale killu selle valdkonnaga tegelemisest Venemaal. ${ }^{4}$ Ehkki tavapäraselt laiendatakse teadusartikleid kommentaari tüüpi artiklitega, on seekord mindud teist teed. Kuna Läti uurijate tööd peegeldavad ka Eesti ajaloos aktuaalseid teemasid - nõukogude aja mõju tänapäeva ühiskonnale, on Maruta Pranka ja Irēna Saleniece artiklitest tõu- 
kuvalt Eesti samalaadest uurimisest kirjutanud Aigi Rahi-Tamm. Lisaks on teemanumbris avaldatud alliktekst: 20. sajandi alguses kirjutatud mina-vormiline olustikuline külalugu Priidik Sarapikult. Selle juurde kuulub Priidik Sarapiku eluloo tutvustus Läänemaa aja- ja koduloo uurijalt Laine Soosalult ning kogu sündmustiku sotsiaalkultuurilisi ja majanduslikke taustasid avav artikkel ajaloolase Tiit Rosenbergi sulest. Ajakirjanumbri need osad on suunatud enam mõtisklema pärimusliku ajaloo alliktekstide mitmeplaanilisuse ja ühtlasi uurimise interdistsiplinaarsete võimaluste üle. Teemanumbris tuleb avaldamisele artikkel Aino Laaguselt, kelle tööd on seotud pärimusliku ajaloo kogumise ja uurimisega. ${ }^{5}$ Tema elu katkes enne tulemuste avaldamist. Seoses tema sünniaastapäevaga on liidetud temaatilise kogumiku tekstide järele tema artikli "Situatsioonianalüüs folkloristikas" taastrükk ning Tiiu Jaago käsitlus selle analüüsi edasiarendustest ja tähendusest tänapäeva pärimusliku ajaloo uurimises.

Alljärgnevas keskendume artiklites kõneks tulevatele metoodilistele ja refleksiivsetele küsimustele.

\section{Mõisted, allikad ja meetodid}

Käesolevas teemanumbris käsitletakse valdkondi 'pärimuslik ajalugu', 'suuline ajalugu' ja 'eluloouurimine'. Neil lähenemisviisidel on omad juured, mida oleme käsitlenud oma varasemates artiklites (Jaago 2001; 2005; 2006a; Jaago \& Kõresaar \& Rahi-Tamm 2006; Kõresaar 2003; 2005b). Kuigi eelkirjeldatud koostöös kui teaduse arengujoone ühes näites on nimetatud valdkondadel ühisala, toovad nende valdkondade varasemad arengud interdistsiplinaarsusse erijoone, mis väljendub nii mõistete kasutamises kui ka meetodite valikus. Eestis on pärimuslik ajalugu (nagu sm muistitietotutkimus) folkloristliku põhjaga (vrd Peltonen 2003) ja see annab pärimusliku ajaloo uurimisele ka oma eripä$\mathrm{ra}$ - tuginemise tekstiuurimisele ja traditsioonilisele jutustamisele. Paralleelselt pärimusliku ajaloo uurimisega kujunes elulugude uurimine, mis huvitus individuaalse ja kollektiivse suhtest ja argielu personaalsest kogemusest. Nende kahe uurimissuuna, pärimusliku ajaloo ja eluloouurimise raames hakkas toimuma dialoog siis, kui pärimusliku ajaloo allikabaas oli avardunud elulugude väljale ning biograafilise meetodi kasutajad olid enam teadvustanud jutustamistasandi ja mälu osa eluloos. Üheks interdistsiplinaarse tööetapi tulemuseks elulugude uurimisel Eestis on artiklite kogumik She who remembers, survives (Kirss \& Kõresaar \& Lauristin 2004).

Paralleelselt kirjeldatuga on Eestis olemas teisedki lähedased uurimisviisid, mis ei seostu otseselt kõnesoleva uurijatevõrgustikuga, aga mida esinda- 
vad näiteks folkloristikas Andreas Kalkuni eluloouurimused (Kalkun 2004) ja Mare Kalda töö ajaloolise jutu-uurimise alalt (Kalda 2007), etnoloogias nõukogude argielu uurimused (Jõesalu \& Ruusmann 2008; Ruusmann 2003; 2006) ja repressioonideuurimused (Anepaio 2003a; 2003b; Rahi-Tamm 2004) ning biograafiline meetod sotsioloogias, milles on esindatud nii elutõlgenduse diskursiivsust kui ka elulaadi spetsiifikat rõhutavad suunad (Aarelaid 2003; 2006; Hatšaturjan 2003; 2007; Nugin 2005).

Rahvusvaheliselt katab rahvuslikke mõisteid 'pärimuslik ajalugu' ja muistitietotutkimus ingliskeelne termin oral history (suuline ajalugu). See on Teise maailmasõja järel ajalooteaduste raames väljakujunenud suund, mis kasutab allikana suulisi intervjuusid ja mõistab ennast ühtlasi nende intervjuude loomise meetodina (Perks \& Thomson 2000). 1970. aastatest alates on toimunud humanitaar- ja sotsiaalteaduste lähenemine, mille raames kohtusid suuline ajalugu, narratiiviuurimine ja biograafiline meetod. Kui see uurimisviis 1990. aastatel Eestis, Lätis ja Leedus esile kerkis, sõltus konkreetse maa teadustraditsioonist, rahvusvahelistest suhetest ja rahvusliku teadusruumi interdistsiplinaarsest potentsiaalist, milline eelnimetatud valdkond hakkas ühe või teise uurija töödes tooni andma.

Uurimisviisi paralleelarengud rahvussiseselt ja -väliselt on tekitanud küsimuse mõiste tõlkimisest: kas oral history on eesti keeles 'pärimuslik ajalugu', 'suuline ajalugu' või kord nii, kord teisiti. Ja vastupidi: kas 'pärimuslik ajalugu' tuleks tõlkida alati oral history'ks või proovida tõlkes esile tuua teatud nihet oral history mõistest. Analoogilist probleemi soome teaduses on käsitlenud Ulla-Maija Peltonen (2003). Käesolevas teemanumbris on lähtutud põhimõttest tuua samalaadne, ent erinevate seesmiste arengutega uurimisviis mõistete kaudu ka esile. Kuna läti uurijad kasutavad ise suulise ajaloo (mutvārdu vēsture) mõistet ega seo seda varasemate Läti teadustraditsioonidega, siis ei ole põhjust seda tõlkida eesti keelde 'pärimuslikuks ajalooks'. Täiesti vastupidine on aga olukord Soome töödega: neis eristatakse vaadeldavaid mõisteid, mistõttu ka eesti keeles on otstarbekas seda eristust arvestada. Hoolimata sellest, et 'pärimuslik ajalugu' ei ole otsetõlge soome muistitietost, on nende, teineteisest sõltumatult kujunenud uurimisviiside seesmised arengud analoogilised.

Ühtlasi erinevad vaadeldavas regioonis ka eelistatavalt kasutatavad allikad: Eestis ja Soomes kasutatakse nii suulisi kui ka kirjalikke, sealhulgas ka kirjalikuna loodud jutustusi. Lätis ja Leedus hõlmavad keskse koha suulised intervjuud.

Jyrki Pöysä sedastab käesolevas ajakirjanumbris, et eluloouurimist ja pärimusliku ajaloo uurimist eristab fookus - eluloouurijad ei keskendu mälul põhinevale ajalookäsitlusele sama palju kui pärimusliku ajaloo uurijad. Lätis 
ja Leedus on eluloouurimine (biograafiline meetod) olnud primaarne suulise ajaloo ees. Ent kuna elulugudes oli esiplaanil inimeste elukäikude ja võimu konflikt, tingis see tööde seostamise suulise ajaloo mõistega. Eestit, Lätit ja Leedut seob sama ajalooline kogemus (ka Eesti elulugudes on esikohal inimese ja võimu konflikt), mis kajastub ka sarnastes uurimisteemades. Samas eristab Eestit lõunanaabritest allikakogumise viis: suuliste intervjuude kõrval on märkimisväärseks allikaks kirjalikud kaastööd. See lähendab Eesti teadusruumi Soome omaga.

Kui Eesti ja Soome uurimusi ühendab teooria, allikate ja meetodite sarnasus, siis Läti ja Leedu uurimusi seovad Eestiga sarnased uurimisteemad, (eriti, mis puudutab nõukogude aja uurimisi). Selles mõttes asetub Eesti eluloo-ja pärimusliku ajaloo uurimine Baltimaade ja Soome teadusruumi vahealale, sisaldades ühisjooni nii ühe kui ka teise regiooni teadustraditsiooniga, moodustades aga sellisena omaette terviku.

\section{Uurija enesepaigutus}

Erinevat liiki allikate kasutuse kõrval on uurimisprotsessi ja -tulemuse seisukohalt oluline uurija positsioon - see, kuidas ta valib oma uurimisallikad ja millised raamid kehtestab oma käsitlusele. Teemanumbrisse valitud artiklid näitavad enesepositsioneerimise mitmekesisust, mis, nagu eelnevalt osutasime, ei ole juhuslik, vaid tuleneb konkreetsest teadussituatsioonist. Ka siin paigutuvad Eesti uurijad Soome ning Läti-Leedu vahele, sisaldades ühisosa nii ühe kui ka teise teadusruumiga, kattumata samas päriselt kummagagi.

Maruta Pranka (Riia) lähtub oma artiklis kodu kui stabiilsuse sümboli ja migratsiooni kui ebastabiilsuse vastandusest. See kehtib tema valitud raamide puhul, milleks on nõukogude-aegne rahvuspoliitika. Põhimõtteliselt võib aga olukorda tõlgendada ka teisiti - migratsioon kui liikumine oma kodu suunas. M. Pranka artiklis õigupoolest esindab seda teemat tagasivaade majaehitajate maja-eelsele elule, kui nad tulevad 20. sajandi alguses maalt linna. Valitud raami tõttu sobitub M. Pranka mikrotasandi käsitlus nõukogude-järgsesse rahvusliku ideoloogiana mõistetavasse makrotasandisse, mis tuleb esile eriti katkestuse diskursuses (vrd Kõresaar 2005a: 198-200).

Kirsti Salmi-Niklander näitab oma artiklis muutusi ühiskonnas mitte elukäikude, vaid tekstianalüüsi kaudu. Erinevalt Maruta Prankast ei võrdle ta mikro- ja makrostruktuuri ilminguid, vaid mikrotasandi tekstide kaudu teeb ta järeldusi makrostruktuuri kohta (nt naiste tulek meeste maailma avalikku sfääri). Mõlemad autorid kirjeldavad ühiskondlikke protsesse, kuid teevad seda erinevalt, kasutades erinevaid allikaid ja meetodeid. Kui sotsioloogi taustaga 


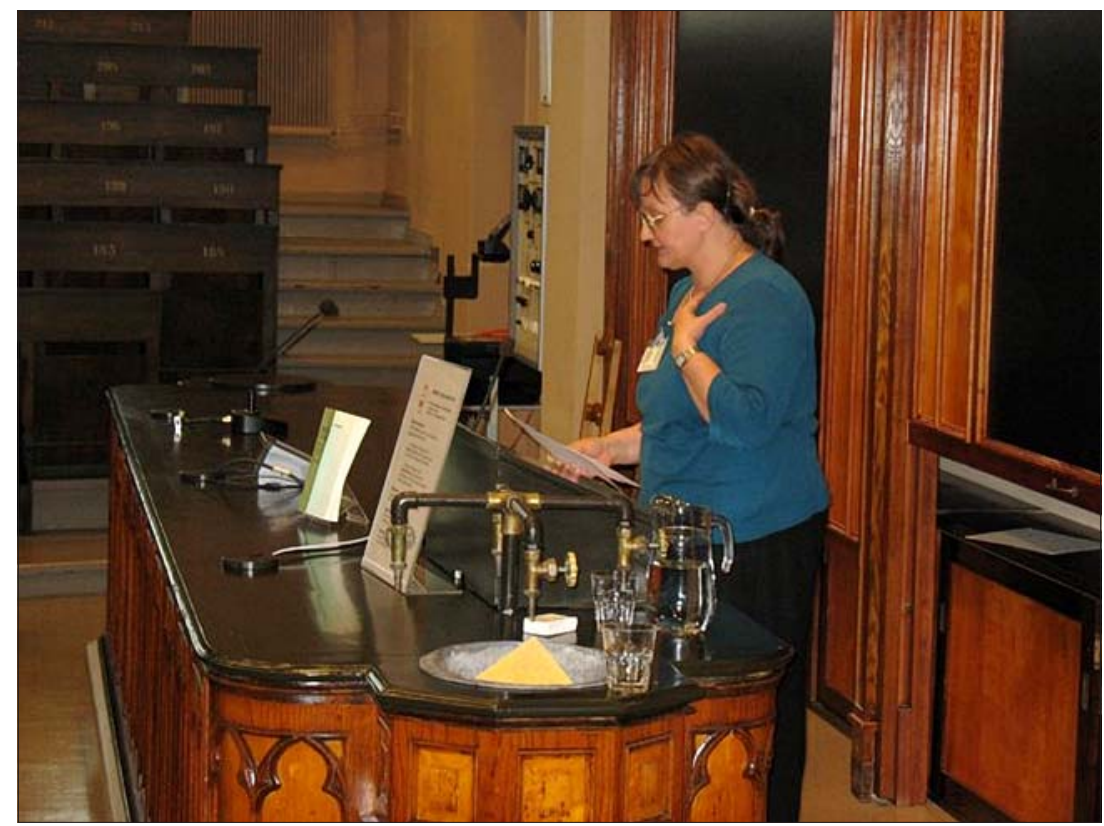

Kirsti Salmi-Niklander pidamas ettekannet pärimusliku ajaloo uurijate rahvusvahelisel konverentsil "Memory and Narration" Helsingis 2006. aastal. Jyrki Pöysä foto 2006.

Maruta Pranka ei küsi üldse tekstiloome tehnikaga seotud küsimusi, siis folklorist Kirsti Salmi-Niklanderi silmis on tekstide kujunemine uuritavate ühiskonnamuutuste osa. Ta vaatleb uute tehnikate (käsikirjaliste ajalehtede jms koostamine ja ettelugemine üritustel) ning uute žanrite kujunemist, mis lähtub ühelt poolt suulisest jutustamistraditsioonist ja teiselt poolt kirjalikest ajalehežanritest.

Eestis keskendub kirjakultuuri ja omaeluloolise jutustamise vaheliste seoste uurimine küsimusele, kuidas inimesed kasutavad erinevaid kultuuritekste, et jutustada oma elust (Jaago 2003a: 196-198; Kõresaar 2006). Kui allikatena kasutatakse nii suulisi kui ka kirjalikke tekste, siis tekib küsimus, kas need (suuliselt ja kirjalikult loodud jutustused) on loomult erinevad. Senised analüüsitulemused on näidanud, et jutustaja esitatud sõnumit erinev esitus (suuline või kirjalik) ei muuda. Küll aga tuleb tähelepanu pöörata jutustamissituatsioonist tulenevatele teksti eripäradele, nt dialoog partneriga intervjuuolukorras pakub uurijale, võrreldes kirjaliku kaastööga ERMile sama loo erinevaid aspekte (Jaago 2006b; 2008: 103, 107; Jõesalu 2003; 2006). See ühtib ka Jyrki Pöysä väitega siinavaldatud artiklis: ka tema jõuab järeldusele, et suuline ja kirjalik jutustus ei tekita erinevaid lugusid (need räägivad ikka nii-öelda samast asjast), kuid need toovad esile teksti loomise asjaoludest tingitud eri- 
nevaid tahke (nt intervjuus luuakse situatiivne mina, mis ei allu jutustaja kontrollile samavõrra, kui pikema perioodi vältel kirjutatud kujuteldav mina).

Jyrki Pöysä läheneb suulise ja kirjaliku tekstiloome probleemile veel teisest vaatepunktist, analüüsides kirjalikke kogumisvõistlusi kui üht allikaloomise viisi. Ta küsib, milliseid žanrilisi aspekte peab kirjalikuna loodud tekstide uurija silmas pidama. Žanrianalüüs võimaldab “üles noppida” tekstides sisalduvaid vihjeid jutustatu sisu ja jutustaja eesmärkide tõlgendamiseks. Ta pakub jutustuse analüüsiks välja meetodi, mis keskendub tekstiosade ja ajatasandite eristamisele.

Irēna Saleniece tegeleb samuti suulise ja kirjaliku teksti küsimustega, ent tema fookus pole mitte niivõrd teksti- kuivõrd tõsielutasandil: kuidas avaldub kirjalikes arhiividokumentides ja suulistes intervjuudes tõde ajaloosündmuse kohta. J. Pöysä ja I. Saleniece erinevad fookusevalikud ilmnevad ka selles, kuidas nad käsitlevad tekstide avaldamisega seotud toimetamisküsimusi. Kui Jyrki Pöysäl on esikohal tekstide esteetiline printsiip (kirjanduslikkus), mis ei kattu alati teadusliku väärtusega, siis Irēna Saleniece tegeleb tekstide avaldamise eetilis-õigusliku aspektiga, kuna tekstid puudutavad isikuõigusi ja andmekaitset.

Soome autorite käsitlustes on esiplaanil tekst ja sellest tulenevalt ühtlaadi allikate süvaanalüüs, Läti autorid keskenduvad aga tõsielule ja sellest lähtuvalt eri allikaliikide kombineerimisele uurimuses. Ometi tegelevad mõlemad ühiskonna uurimisega.

Eestis on erinevat laadi allikate kooskasutamisel olnud esiplaanil küsimus ajast: ${ }^{6}$ kuidas suhestuvad jutustamise aeg ja jutustatava sündmuse aeg ning protsessid, mis jäävad nende kahe vahele ja ümber. Siin ei asetu rõhk mitte niivõrd tõesusele (vt Irēna Saleniece artiklit), kuivõrd näiteks jututraditsiooni kujunemistendentsidele, s.o kuidas aitavad ajaloodokumendid mõista jututraditsiooni arengujoont (Jaago 1995, 2006b), samuti küsimustele ajaloopiltide vahelistest seostest (Jaago \& Kõresaar 2008) ning jutustamisaja ja jutustatava aja dialoogist (Jõesalu 2003; 2006).

Uurija enesepaigutusega on seotud ka terminoloogia. Kirsti Salmi-Niklander pöörab tähelepanu asjaolule, et mõisted ei ole absoluutsed, ja et isegi näiliselt lihtsaid mõisteid - nagu antud juhul 'sündmus' - tuleb defineerida. Käesolevas teemanumbris tulevad sündmuse mõiste erinevused esile nii tegija, kogeja kui ka aja vaatepunktist. 20. sajandi lõpu elulugude kirjutajad ja lugejad on harjunud sündmuste kiire vaheldumisega ja hästi piiritletud, välja joonistatud esitusega. Kirsti Salmi-Niklander analüüsib 20. sajandi alguses loodud tekste, mille analoogiks on käesolevas numbris avaldatud alliktekst, Priidik Sarapiku jutustus "Matsalu": see on laadilt sarnane Kirsti Salmi-Niklanderi analüüsitud tekstidele - suulise ja kirjaliku piiril olevatele sünkroonsetele sündmusjutus- 
tustele. Kui aga vaadata seda teksti tänapäeva lugejakogemusest lähtudes, siis tundub, nagu sündmust selles loos polekski, nii aeglaselt kulgeb seal tegevus.

Tänapäeva ühiskonna üks aktuaalne arutelu märtsiküüditamise kui sündmuse ümber avaldub Aigi Rahi-Tamme kirjutises. Ta näitab, kuidas sündmuse läbielanute (kogejate) ja ajaloolase vaatepunktidest lähtuvad teadmised satuvad omavahel vastuollu: kummagi allikad on erinevad ja sellest johtuvalt kõnelevad nad sündmuse erinevatest tasanditest. Analoogilise näitena, kuidas on omavahel seotud vaatleja, sündmus ja väljendus, võib tuua sünnitusjutud: sünni meditsiiniline kirjeldus arsti vaatevinklist, sünni fikseerimine sünnitunnistusel, vanemate repertuaaris olevad sünnilood (vt nt Nilsson 2003) ja teiste sünni juures vahetult olnud inimeste jutud (Maripuu 2009) - kõik räägivad ühest ja samast sündmusest, kuid lähtuvad erinevatest perspektiividest ja kasutavad erinevaid stiilivõtteid. Kõik kirjeldajad saavad sündmusi tekstis konstrueerida ainult selles raamis, mis on kirjeldaja ja teksti eesmärk, millele kirjeldaja saab tugineda ja milline on formaat, kuhu ta peab kirjelduse paigutama. Kõike seda tuleb arvestada pärimusliku ajaloo uurimisel.

Käesolev ajakirjanumber on kirjeldatud koostöö üks etapp, mitte lõpp-punkt. Loodame, et selle teemanumbriga tekivad uued dialoogiliinid. Eesmärgiks on juhtida tähelepanu erinevate allikate, meetodite ja mõistete ühisosale, aga ka spetsiifikale. Olemasolevat võimalikult üksikasjalikult esitledes luuakse kogemus, mis omakorda võimaldab nüansirikkamalt näha ja käsitleda pärimuslikku ajalugu ja omaeluloolisi allikaid.

\section{Kommentaarid}

1 Artikli ilmumist on toetanud ETF grant 6687 ning Euroopa Liit Euroopa Regionaalarengu Fondi kaudu (Kultuuriteooria Tippkeskus).

${ }^{2}$ Käesolev teemanumber keskendub ühe koostöövõrgustiku tegevusele. Paralleelseid ja osalt kattuvaid liine vt nt Hinrikus \& Kõresaar 2004: 23.

${ }^{3}$ Vt lisaks eelnimetatud artiklite kogumikule Pärimuslik ajalugu artikleid kogumikust Pärimus ja tõlgendus (Jaago 2003), soome folkloristika e-ajakirja Elore pärimusliku ajaloo teemanumbrit (Elore 2006), Läti Ülikooli filosoofia- ja sotsioloogia teaduskonna väljaannet Spogulis (Peegel, Zirnīte 2007.)

${ }^{4}$ Gulsina Seljaninova, osaledes pärimusliku ajaloo konverentsidel ja eriti sõjateemalistel seminaridel Soomes 2006. aastal, otsis aktiivselt kontakti Eesti pärimusliku ajaloo uurijatega. See ärgitas temalt tellima ülevaadet uurimistööst tema koduülikoolis käesoleva teemanumbri jaoks.

5 Aino Laagus, töötades aastail 1993-1999 Lundi ülikooli juures, juhtis Euroopauuringute keskuse finantseeritavaid projekte, mille käigus intervjueeriti LõunaRootsis elavaid eestlasi ja korraldati seminare. Helsingi ülikooli juures töötades 
(2000-2004) ärgitas ta oma õpilasi ja kolleege tegelema eestlaste elulugudega, mille üheks väljundiks on Mäetaguste 16. numbris avaldatud Leena Huima artikkel "Saatuse tahtel".

${ }^{6}$ Üldistavalt võib öelda, et aja ja jutustamise seosed ongi üks keskseid küsimusi Eesti teaduses, seda ka üht tüüpi allikate uurimisel. Vt nt aja semiootilist käsitlust kirjandustekstis Veidemann 2002; ajasünkretismi ilmingute käsitlusi elulootekstis Kõresaar 2003; Reinvelt 2003.

\section{Kirjandus}

Aarelaid-Tart, Aili 2003. Double mental standards in the Baltics during two afterwar decades in Baltics. Kõll, Anu-Mai (toim). The Baltic countries under occupation: Soviet and Nazi rule 1939-1991. Studia Baltica Stockholmiensia 23. Stockholm: Stockholm University, Department of History, lk 213-226.

Aarelaid-Tart, Aili 2006. Cultural Trauma and Life Stories. Helsinki: University of Helsinki (http://ethesis.helsinki.fi/julkaisut/val/sospo/vk/aarelaid-tart/cultural.pdf 7. oktoober 2009).

Anepaio, Terje 2003a. Boundaries in the Soviet society - the case of the repressed. Korhonen, Teppo \& Ruotsala, Helena \& Uusitalo, Eeva (toim). Making and breaking of borders. Ethnological interpretation, presentation, representation. Helsinki: Finnish Literature Society, lk 67-78.

Anepaio, Terje 2003b. Eesti mäletab!? Repressiooniteema retseptsioon Eesti ühiskonnas. Kõresaar, Ene \& Anepaio, Terje (toim). Mälu kui kultuuritegur: etnilisi perspektiive. Tartu: Tartu Ülikool, lk 206-230.

Bela-Krūmina, Baiba 2001. Tavaliselt mahavaikitud. Muutuv maailm apoliitilises eluloos. Jaago, Tiiu (koost). Pärimuslik ajalugu. Tartu: Tartu Ülikooli Kirjastus, lk 132-136.

Elore 13 (1), 2006. http://www.elore.fi/arkisto/1_06/elore1_06.html - 7. oktoober 2009.

Hatšaturjan 2003 = Hachaturyan-Kisilenko, Aida 2003. An Attempt to Describe Life in a Soviet Military Garrison, through Biographical Material. Pro Ethnologia 16, lk 99-112 (http://www.erm.ee/pdf/pro16/hachaturyan-kisilenko.pdf - 7. oktoober 2009)

Hatšaturjan, Aida 2007. 'Ноmo urbanis' советского военного городка. Поляков, Юрий \& Тарле, Галина \& Будницкий, Олег (toim). История российского зарубежья: Эмиграция из СССР-России. 1941-2001. Москва: Российская Академия Наук, Институт российской истории, lk 245-268.

Hinrikus, Rutt \& Kõresaar, Ene 2004. A Brief Overview of Life History Collection and Research in Estonia. Kirss, Tiina \& Kõresaar, Ene \& Lauristin, Marju (toim). She who remembers survives: interpreting Estonian women's post-Soviet life stories. Tartu:Tartu University Press, lk 19-34.

Jaago, Tiiu 1995. Suulise traditsiooni eripära vaimses kultuuris. Perepärimuse põhjal. Pro Ethnologia 3, lk 116-121 (http://www.erm.ee/?node=113 - 7. oktoober 2009). 
Jaago, Tiiu 1999. Ääremõtteid Pauliina Latvala artiklile "Soomlase elu kujutamine pärimuslikus ajaloos”. Mäetagused 11, lk 88-92 (http://www.folklore.ee/tagused/authors/ tjaago.htm - 7. oktoober 2009)

Jaago, Tiiu (koost) 2001. Pärimuslik ajalugu. Tartu: Tartu Ülikooli Kirjastus.

Jaago, Tiiu 2003a. "See kõik oli nii, nagu tundsin ja mõtlesin." Ühe naise elulugu pärimusliku ajaloo vaatepunktist. Jaago, Tiiu (koost). Pärimus ja tõlgendus. Artikleid folkloristika ja etnoloogia teooria, meetodite ning uurimispraktika alalt. Tartu: Tartu Ülikooli Kirjastus, lk 191-210.

Jaago, Tiiu (koost) 2003b. Pärimus ja tõlgendus. Artikleid folkloristika ja etnoloogia teooria, meetodite ning uurimispraktika alalt. Tartu: Tartu Ülikooli Kirjastus.

Jaago, Tiiu 2005. Pärimuslik ajalugu ja Fr. R. Kreutzwald. Õpetatud Eesti Seltsi aastaraamat 2003. Tartu: Tartu Ülikooli Kirjastus, lk 9-20.

Jaago, Tiiu 2006a. Pärimusliku ajaloo uurimine. Jaago, Tiiu (toim). Argikultuuri uurimise terminoloogia e-sõnastik. Tartu Ülikool, eesti ja võrdleva rahvaluule osakond. http://argikultuur.e-uni.ee - 7. oktoober 2009).

Jaago, Tiiu 2006b. Critical events of the 1940s in Estonian life histories. Sign Systems Studies 34 (2). Tartu: Tartu University Press, lk 471-492.

Jaago, Tiiu 2008. Ruumi kujutamine eluloos: küsimus tõsielujutustuse žanrist. Jaago, Tiiu (koost). Ruumi loomine. Artikleid keskkonna kujutamisest tekstides. Studia Ethnologica et Folkloristica Tartuensia 11. Tartu: Tartu Ülikooli Kirjastus, lk 99-119.

Jaago, Tiiu \& Kõresaar, Ene \& Rahi-Tamm, Aigi 2006. Oral History and Life Stories as a Research Area in Estonian History, Folkloristics and Ethnology. Elore 13 (1). http://www.elore.fi/arkisto/1_06/jkr1_06.pdf - 7. oktoober 2009).

Jaago, Tiiu \& Kõresaar, Ene 2008. Complementarity of Sources in Studying Adaptation: an Oral History Viewpoint. Folklore. Electronic Journal of Folklore 39. Eriväljaanne Folk Narrative and Contemporary Practices VI, lk 17 - 38 . http://www.folklore.ee/ folklore/vol39/jaago_koresaar.pdf - 7. oktoober 2009).

Jõesalu, Kirsti 2003. What People Tell about Their Working Life in the ESSR, and How Do They Do It? Source-centred Study of a Civil Servant's Career Biography. Pro Ethnologia 16, lk 61-88 (http://www.erm.ee/?node=451\&lang=est - 7. oktoober 2009).

Jõesalu, Kirsti 2006. Privaatse ja avaliku põimumisest Nõukogude Eesti eluilmas: postsotsialistlikke vaateid sotsiaalsetele suhetele nõukogude argielus. Eesti Rahva Muuseumi aastaraamat XLIX. Tartu: Eesti Rahva Muuseum, lk 91-124(http:// www.erm.ee/?lang=est\&node=797\&parent=32 - 7. oktoober 2009).

Jõesalu, Kirsti \& Ruusmann, Reet 2008. Personal Networks, Hobby Worlds, and NonProfit Organisations as Sources of Social Capital. On the Basis of Estonian Biographical Materials. Roth, Klaus (toim). Sozialkapital - Vertrauen - Rechtssicherheit. Postsozialistische Gesellscahften und die Europäische Union. Zürich: Lit-Verlag, lk 205-227.

Kalda, Mare 2007. Mõisakingsepa isikukogemuse lugu. Rõngu kirikuraamatus ja muistendikogumikes. Mäetagused 35, lk 95-114 (http://www.folklore.ee/tagused/nr35/ kalda.pdf - 7. oktoober 2009).

Kalkun, Andreas 2004. Anne Vabarna nina. Tõest ja valest seto naiste autobiograafilistes lauludes. Sarv, Mari (toim). Regilaul - loodud või saadud? Tartu: Eesti Kirjan- 
dusmuuseum. Eesti Rahvaluule Arhiiv \& Eesti Kultuuriloo ja Folkloristika Keskus, lk 29-49.

Kirss, Tiina \& Kõresaar, Ene \& Lauristin, Marju (toim) 2004. She who remembers, survives: interpreting Estonian women's post-Soviet life stories. Tartu: Tartu University Press.

Kõresaar, Ene 1999. Märkused ja kommentaarid: Pauliina Latvala "Soomlase elu kujutamine pärimuslikus ajaloo". Mäetagused 11, lk 93-97 (http://www.folklore.ee/tagused/authors/koresaar.htm - 7. oktoober 2009).

Kõresaar, Ene 2003. Eluloolisest käsitlusviisist Eesti kultuuriteadustes. Jaago, Tiiu (koost). Pärimus ja tõlgendus. Artikleid folkloristika ja etnoloogia teooria, meetodite ning uurimispraktika alalt. Tartu: Tartu Ülikooli Kirjastus, lk 61-76.

Kõresaar, Ene 2005a. Elu ideoloogiad. Kollektiivne mälu ja autobiograafiline minevikutõlgendus eestlaste elulugudes. Eesti Rahva Muuseumi sari 6. Tartu: Eesti Rahva Muuseum.

Kõresaar, Ene 2005b. Elulugu. Jaago, Tiiu (toim). Argikultuuri uurimise terminoloogia e-sõnastik. Tartu Ülikool, eesti ja võrdleva rahvaluule osakond (http://argikultuur.euni.ee - 7. oktoober 2009).

Kõresaar, Ene 2006. Kollektives Gedächtnis und nationale Textgemeinschaft im postsowjetischen Estland: Ein Beispiel über die intertextuelle Verwendung des Nationalepos "Kalevipoeg" in den estnischen Lebensgeschichten. Bartens, Hans-Hermann \& Röhrborn, Klaus \& Sagaster, Klaus \& Winkler, Eberhard (toim). Ural-Altaische Jahrbücher. Internationale Zeitschrift für uralische und altaische Forschung. Neue Folge 20. Wiesbaden: Harrassowitz, lk 101-124.

Latvala, Pauliina 1999. Soomlase elu kujutamine pärimuslikus ajaloos. Mäetagused 11, lk 72-87 (http://www.folklore.ee/tagused/ - 7. oktoober 2009).

Maripuu, Kerttu 2009. Meeste jutud sünnitustest: vaade sünnitusele mees- ja jutu-uurimuslikust aspektist. Bakalaureusetöö. Tartu: Tartu ülikooli eesti ja võrdleva rahvaluule osakond (käsikiri).

Nilsson, Bo G. 2003. Sünnilood rootsi tööliste mälestustes. Jaago, Tiiu (koost). Pärimus ja tõlgendus. Artikleid folkloristika ja etnoloogia teooria, meetodite ning uurimispraktika alalt. Tartu: Tartu Ülikooli Kirjastus, lk 211-217.

Nugin, Raili 2005. Diskursused täiskasvanustaatusest: maailm ja Eesti. Estonian Social Science Online (http://www.sotsioloogia.ee/vana/esso3/16/raili_nugin.htm - 7. oktoober 2009)/).

Peltonen, Ulla-Maija 2003. Suuline ajalugu soome folklooriuurimises. Jaago, Tiiu (koost). Pärimus ja tõlgendus. Artikleid folkloristika ja etnoloogia teooria, meetodite ning uurimispraktika alalt. Tartu: Tartu Ülikooli Kirjastus, lk 177-190.

Perks, Robert \& Thomson, Alistair (toim) 2000 [1. tr. 1998]. The oral history reader. London \& New York: Routledge.

Rahi-Tamm, Aigi 2004. One Among a Thousand: The Story of a Deportee's Destiny in the Eyes of an Historian. Kirss, Tiina, Kõresaar, Ene \& Lauristin, Marju (toim). She who remembers, survives. Interpreting Estonian women's post-soviet life stories. Tartu: Tartu University Press, lk 78-88. 
Reinvelt, Riina 2002. Ingeri elud ja lood. Kultuurianalüütiline eluloouurimus. Studia Ethnologica Tartuensia 5. Tartu: Tartu Ülikool.

Ruusmann, Reet. 2003. The Establishment of Collective Farm and Their Early Years as an Image of History in the Estonians' Life Stories. Pro Ethnologia 16, lk 21-38.

Ruusmann, Reet 2006. Defitsiit kui osa nõukogudeaegsest argielust Eesti NSV-s. Eesti Rahva Muuseumi aastaraamat XLIX. Tartu: Eesti Rahva Muuseum, lk 125-156.

Salmi-Niklander, Kirsti 2001. Kelmid ja kangelased, preestrid ja jutlustajad. Usk ja sotsialism kanadasoomlaste kaevurikogukonna suulis-kirjanduslikus traditsioonis. Jaago, Tiiu (koost). Pärimuslik ajalugu. Tartu: Tartu Ülikooli Kirjastus, lk 91-109.

Veidemann, Rein 2002. Aja semiootika. Veidemann, Rein (toim). Aeg ja kirjandus. Artikleid ajakategooria käsitusest, kasutamisest ja toimimisest tekstides. Studia Litteraria Estonica 4. Tartu: Tartu Ülikool, lk 9-35.

Zirnīte, Māra (toim) 2007. Spogulis. Dzīvesstāsti: vēsture, kultūra, sabiedrība. Riga: Latvijas Universitātes, Filosofijas un socioloǵijas institūts, Latvijas Nacionālā Mutvārdu Vēsture.

\section{Summary}

\section{Oral History Research in the Collaboration Space of Estonia and the Neighbouring Countries}

\section{Tiiu Jaago \& Ene Kõresaar}

Key words: Baltic and Finnish collaboration, event, life history research, oral and written culture, oral history

The article provides an overview of the collaboration of oral history researchers and life history researchers in Estonia with researchers from Latvia, Lithuania and Finland. This is an interdisciplinary collaboration, which has formed over the past 12 years and unites folklorists from Finland, sociologists from Latvia and Lithuania, and researchers of different disciplines from Estonia. The Estonian term pärimuslik ajalugu ('oral history') is dealt with in the context of the related concepts of 'oral history' and 'life history research' ('biographical method'). The article focuses on the points of convergence and differences in methods, terminology, and research problems, which have revealed in the course of the collaboration. It is shown how the research (from terminology to research problems) is connected with the historical dimension of the development of research on the one hand, and with the dialogue in a common space of thought, on the other hand. The article observes in more detail the confluence of ideas in the dialogue of the mentioned collaboration space; these are grouped into the categories 'oral', 'written', and 'event', and represent a combination of experience, reality, and expression. 